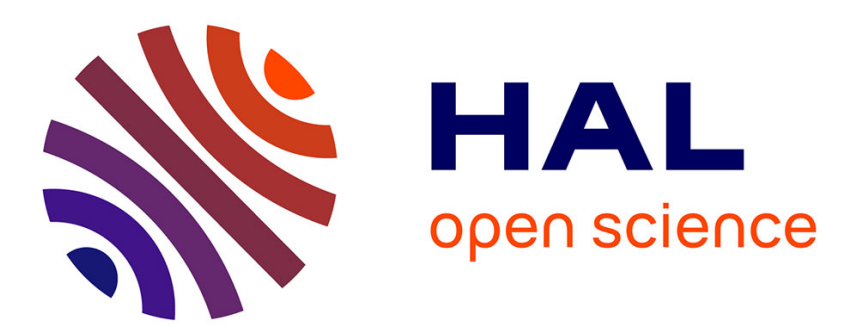

\title{
In search of cues discriminating West-african accents in French
}

Philippe Boula de Mareüil, Jean-Luc Rouas, Manuela Yapomo

\section{To cite this version:}

Philippe Boula de Mareüil, Jean-Luc Rouas, Manuela Yapomo. In search of cues discriminating West-african accents in French. Interspeech, Aug 2011, Florence, Italy. pp.725-728. hal-00664512

\section{HAL Id: hal-00664512 \\ https://hal.inria.fr/hal-00664512}

Submitted on 30 Jan 2012

HAL is a multi-disciplinary open access archive for the deposit and dissemination of scientific research documents, whether they are published or not. The documents may come from teaching and research institutions in France or abroad, or from public or private research centers.
L'archive ouverte pluridisciplinaire $\mathbf{H A L}$, est destinée au dépôt et à la diffusion de documents scientifiques de niveau recherche, publiés ou non, émanant des établissements d'enseignement et de recherche français ou étrangers, des laboratoires publics ou privés. 


\title{
In search of cues discriminating West-African accents in French
}

\author{
Philippe Boula de Mareüil $^{1}$, Jean-Luc Rouas ${ }^{1,2}$, Manuela Yapomo ${ }^{1}$ \\ ${ }^{1}$ LIMSI-CNRS, Orsay, France \\ ${ }^{2}$ LABRI, Bordeaux, France \\ philippe.boula.de.mareuil@limsi.fr, jean-luc.rouas@labri.fr, manuela.yapomo@limsi.fr
}

\begin{abstract}
This study investigates to what extent West-African French accents can be distinguished, based on recordings made in Burkina Faso, Ivory Coast, Mali and Senegal. First, a perceptual experiment was conducted, which suggested that these accents are well identified by West-African listeners (especially the Senegal and Ivory Coast accents). Second, prosodic and segmental cues were studied by using speech processing methods such as automatic phoneme alignment. Results show that the Senegal accent (with a tendency toward word-initial stress followed by a falling pitch movement) and the Ivory Coast accent (with a tendency to delete/vocalise the $/ \mathrm{R} /$ consonant) are most distinct from standard French and among the West-African accents under investigation.

Index Terms: accent identification, perception, prosody, automatic alignment, French sociophonetics.
\end{abstract}

\section{Introduction}

French is spoken in a number of African countries in addition to endogenous languages. Does a form of "African French" emerge, even though speakers have different mother tongues and sociolinguistic environments? What are the phonetic differences across French varieties spoken in Africa? These questions are at the centre of studies focused on Senegal [11] and Mali [10]. The present paper expands on these studies, including these countries and other West-African countries. A perceptual experiment was conducted, based on speech samples recorded in Burkina Faso, Ivory Coast, Mali and Senegal (in the economic capitals of these countries) within the framework of the "Phonology of Contemporary French" (PFC) project [8].

The speakers' mother tongues - Bambara, Moore, Senufo, Akan (or $K w a$ ) languages - have very different phonological systems. The Wolof language, spoken in Senegal, differs maybe more from the other languages in that it is a stress language (stress bearing on word-initial syllables) whereas the other ones are tone languages. One can thus wonder if the French variety spoken in Senegal (where Wolof is spoken by over $75 \%$ of the population [7]) also contrasts with the other West-African French varieties. The Wolof accent in French was successfully identified by listeners from Senegal [11] in a study whose speaker sample, however, did not comprise Malians. On the other hand, [10] found that Malian accents in French (e.g. Bambara and Senufo) are often confused. Only Northern speakers (Tamasheq and Songhay, whose mother tongues are also non-tone languages) are distinguished satisfactorily. In these plurilingual countries, the status of French may also play a role [3]. Some work exists on pronunciation peculiarities in the countries under investigation $[5 ; 4 ; 10 ; 6 ; 7]$. Yet, phonetic differences across French varieties spoken in West Africa are not well known.
The corpus is described in Section 2. Are West-African listeners able to distinguish various accents in French? This question is addressed in Section 3, throughout a perceptual experiment. Identification results are presented as well as a preliminary study of the hand-labelled stimuli used (and commented by the listeners) in the perceptual experiment. In Section 4, a larger subset of the corpus is analysed acoustically, making use of automatic phoneme alignment. Section 5 provides a summary of the discriminant cues that were found and opens perspectives for future work.

\section{Corpus}

In total, 52 speakers were recorded (11 in Burkina Faso, 13 in Ivory Coast, 12 in Mali and 16 in Senegal), with for each speaker the reading of a 400 -word text (about 5 minutes) and 10-15 minutes of spontaneous speech (directed interviews and free conversations). The speakers (of varied age brackets and educational backgrounds) belonged to various ethnic groups.

In the perceptual experiment reported in the next section, 20 talkers speaking French were used (11 males, 9 females, aged 47 years on average). There were as many Akan, Bambara, Moore, Senufo and Wolof speakers, as many speakers who had passed and had not passed the baccalauréat. The possible influence of the education level was tested because it is often put forth in studies on speech variation in Africa (e.g. [10]).

In Section 4, the speech productions of these subjects and the other West-African speakers (native speakers of the above languages or of additional languages such as Fulfulde, Tamasheq, Songhay) were compared to those of speakers who represented a more "standard" French variety (11 speakers from Normandy and 10 speakers from the Paris region). These speakers were also recorded in their place of residence or in a quiet place, following the PFC protocol.

\section{Perceptual experiment and preliminary analysis}

\subsection{Perceptual experiment: protocol and results}

For each of the 20 speakers kept for the perceptual experiment, two speech samples were selected: a read sentence (30 words) and a spontaneous speech excerpt of about 10 seconds. The read sentence, taken from the PFC text, was identical for all speakers: "Beaulieu préfère être inconnue et tranquille plutôt que de se trouver au centre d'une bataille politique dont, par la télévision, seraient témoins des millions d'électeurs". The spontaneous speech excerpt was selected according to the following criteria: assertive utterance whose length was equivalent to that of the read sentence, absence of cultural, spatial or socio-economic references, absence of lexical or syntactic features which could be typical of a particular origin.

The 40 resulting stimuli were administered (in random order) to 20 graduate West-African listeners. These subjects (7 
males, 13 females, aged 35 years on average) were mainly from Ivory Coast. Their task (between other things) consisted of identifying the speaker's country among four possibilities: Burkina Faso, Ivory Coast, Mali and Senegal. Results are shown in Table 1.

Table 1. Confusion matrix resulting from the perceptual test on the speakers' country (\%).

\begin{tabular}{|l|c|c|c|c|}
\hline $\begin{array}{l}\text { response } \\
\text { origin }\end{array}$ & $\begin{array}{c}\text { Burkina } \\
\text { Faso }\end{array}$ & $\begin{array}{c}\text { Ivory } \\
\text { Coast }\end{array}$ & Mali & Senegal \\
\hline $\begin{array}{l}\text { Burkina } \\
\text { Faso }\end{array}$ & $\mathbf{4 1}$ & 36 & 23 & 0 \\
\hline Ivory Coast & 9 & $\mathbf{7 5}$ & 16 & 1 \\
\hline Mali & 19 & 19 & $\mathbf{5 6}$ & 6 \\
\hline Senegal & 4 & 2 & 10 & $\mathbf{8 3}$ \\
\hline
\end{tabular}

On average, the speakers' country was correctly identified in $63 \%$ of cases. For each country, the majority answer is the right one, even though the majority is only relative for Burkina Faso. Interestingly, yet, the latter country is never confused with Senegal (the best identified country, in $83 \%$ of cases).

An analysis of variance (ANOVA) was performed on the responses counted as right (1) or wrong (0) with the random factor Subject, the Type of speech (read or spontaneous) and the Education level (baccalauréat or not) as within-subject factors. The effect of Type of speech was not significant, even though the country was identified slightly better in reading than in spontaneous speech (in $64 \%$ vs. $62 \%$ of cases). The effect of Education level was not significant either - speakers who had passed the baccalauréat being slightly better identified than the others (in $66 \%$ vs. $60 \%$ of cases).

At the end of the test, ten subjects commented on clues which helped them identify the speakers' origin. Suprasegmental (or prosodic) cues were mentioned, almost always associated with Senegal. Among segmental features, the $/ \mathrm{R} /$ realisation was the pronunciation trait most often reported: in Africa, the French dorsal / $\mathrm{S} /$ may be apical ([C]), labialised ([w]) or elided. The articulation of stop consonants was also cited, but these segmental features were not precisely associated with a given country.

\subsection{Salient cues: preliminary analysis}

In the experiment corpus, measurements inspired by listeners' comments were made on prosody, the $/ \mathrm{R} /$ and stop consonants.

To quantify prosodic tendencies, we measured the difference of fundamental frequency $\left(\Delta F_{0}\right)$ between the final vowel and the initial vowel of four words of the read sentence which were the object of various comments. These words, repeatedly pronounced by all the speakers, were bataille ('fight'), politique ('political'), inconnue ('unknown') and tranquille ('quiet'). $F_{0}$ was extracted by using the PrAAT software [1] default settings. $\Delta F_{0}$ values in semitones (ST) were then averaged for each investigation point. Results are presented in Table 2.

Table 2. Average $\Delta \mathrm{F}_{0}$ (in semitones) between the final and initial vowels of four words belonging to the read sentence of the perceptual experiment.

\begin{tabular}{|c|c|c|c|}
\hline $\begin{array}{c}\text { Burkina } \\
\text { Faso }\end{array}$ & Ivory Coast & Mali & Senegal \\
\hline 1.5 & 2.6 & 1.3 & -1.7 \\
\hline
\end{tabular}

The only negative $\Delta F_{0}$ value is observed in Senegal. On average, Senegalese speakers exhibit more initial stresses followed by falling pitch movements, in line with the prosodic system of their mother tongue (Wolof), whereas French is traditionally said to posess a phrase-final stress. This tendency (exemplified in Figure 1) may be interpreted as a prosodic transfer from Wolof to French.

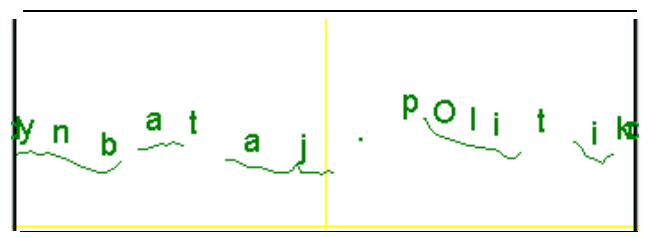

Figure 1: $\mathrm{F}_{0}$ curve of the sequence une bataille politique ('a political fight') read by a Senegalese speaker.

As regards the $/ \mathrm{R} /$ pronunciation, there were $283 / \mathrm{R} /$ occurrences in the stimuli of the perceptual experiment, which were annotated manually by an expert. Results broken down into three categories (apical, dorsal, elided or labialised) are reported in Table 3.

Table 3. Percentage of apical, dorsal, elided or labialised $/ R / s$ in the perceptual experiment stimulit

\begin{tabular}{|c|c|c|c|c|}
\hline$\% / \mathrm{R} /$ & $\begin{array}{c}\text { Burkina } \\
\text { Faso }\end{array}$ & $\begin{array}{c}\text { Ivory } \\
\text { Coast }\end{array}$ & Mali & Senegal \\
\hline apical [r] & 71 & 39 & 91 & 59 \\
dorsal [6] & 5 & 10 & 0 & 23 \\
elided or & 24 & 51 & 9 & 18 \\
labialised [w] & & & & \\
\hline
\end{tabular}

A majority of elision/labialisation cases can be noticed in Ivory Coast, while Senegal (among the 4 countries) shows the highest percentage of dorsal $[\mathrm{K}] \mathrm{s}$. A tendency to pronounce $/ \mathrm{R} / \mathrm{s}$ in the French way was also observed in Wolof [12]. By contrast, a majority of apical [ $\mathrm{r}] \mathrm{s}$ is observed in Mali and Burkina Faso.

For stop consonants, Voice Onset Time (VOT) measurements were made. Defined as the time interval between the release of the stop and the onset of periodic vibrations (that is, voicing), VOT is an important cue to stop voicing and place of articulation [14]. It was measured on 703 occurrences of stop consonants appearing in the stimuli of the perceptual experiment: unvoiced stops (for which VOT is about $20 \mathrm{~ms}$ ) and voiced stops (for which VOT is negative, around $-60 \mathrm{~ms}$ ). These values (see Table 4) fall within the range of values measured for standard French [14]. The increase of VOT (among [p t k] especially) is also expected.

Table 4. VOT of stop consonants in the perceptual experiment stimuli.

\begin{tabular}{|c|c|c|c|c|}
\hline $\begin{array}{c}\text { VOT } \\
(\mathrm{ms})\end{array}$ & $\begin{array}{c}\text { Burkina } \\
\text { Faso }\end{array}$ & $\begin{array}{c}\text { Ivory } \\
\text { Coast }\end{array}$ & Mali & Senegal \\
\hline$[\mathrm{p}]$ & 17 & 12 & 14 & 15 \\
{$[\mathrm{t}]$} & 26 & 23 & 23 & 20 \\
{$[\mathrm{k}]$} & 31 & 29 & 33 & 29 \\
\hline$[\mathrm{b}]$ & -66 & -65 & -55 & -65 \\
{$[\mathrm{~d}]$} & -58 & -62 & -61 & -70 \\
{$[\mathrm{~g}]$} & - & -54 & -42 & -49 \\
\hline
\end{tabular}


From the figures of Table 4, no significant cross-variety difference emerges. This VOT parameter was not considered in the following section. In the remainder of this paper, $\Delta F_{0}$ prosodic patterns and the $/ \mathrm{R} /$ pronunciation were analysed on the basis of text reading. Since the speakers' country was well identified (with non-significant differences between read and spontaneous speech), we should be able to find out discriminant acoustic cues in this directly comparable read speech material.

\section{Analysis of the read text}

\subsection{Method}

The text read by the 52 West-African speakers and the 21 French speakers was segmented and phone-labelled by using automatic phoneme alignment. From a speech signal and its orthographic transcription (here, the fine-grained transcript of the text as actually read by the speakers), given acoustic models as well as a pronunciation dictionary which may include variants, the decoder provides the most likely sequence of phonemes. The LIMSI system [9] was used as in [15] with context-independent acoustic models.

Two types of alignment were performed: a standard alignment for prosody analysis and a forced alignment with pronunciation variants for the $/ \mathrm{R} /$ realisation analysis. In this second alignment, the variants $[\mathrm{K}|\mathrm{r}| \mathrm{w}]$ were allowed. The acoustic model set was enriched with Spanish acoustic models for the apical $[\mathrm{r}]$ since the latter does not belong to the phonemic repertoire of standard French, and a new pronunciation dictionary was built. The $/ \mathrm{R} /$ elision was also possible in the alignment. (Underlying pronunciations are conventionally capitalised and noted between slashes; nonstandard variants are noted between square brackets since they refer to phonetic realisations.) Alignment rates were then computed, simulating a categorisation into dorsal [в], apical [r], elided or labialised [w].

\subsection{Prosody analysis}

$F_{0}$ was measured every $10 \mathrm{~ms}$ by using both PRAAT and the WaveSurfer SNACK pitch tracker [2]. Two ways of assigning a single $F_{0}$ value to each phoneme delimited by automatic alignment were also compared. The first one consisted of averaging all the available measures for each phoneme. The second one consisted of considering phonemes voiced on at least $70 \%$ of their frames for averaging $F_{0}$ values - otherwise, phonemes were considered as unvoiced. Whatever the tool and the method used, very similar results are obtained. Only results achieved by averaging PRAAT measures taken every $10 \mathrm{~ms}$ will be presented.

Two types of analysis were carried out to follow pitch movements. The first one took into account all polysyllabic words (that is, words containing at least two vowels and possibly a final schwa). There were 127 different polysyllabic word types in the PFC text (e.g. village, Beaulieu). Words such as virgule ('comma') or parenthèse ('parenthesis'), which could be produced by the speakers, were not considered because they were not part of the text. This yielded at least 1000 occurrences per investigation point. The second analysis focused on clitic-polysyllabic word sequences. For clitics, we considered frequent function words such as le, la, les ('the'). There were 20 different clitic word types in the PFC text, yielding at least 500 clitic-polysyllabic word contexts such as une bataille ('a fight') per investigation point.

The $F_{0}$ difference (in semitones) between the final and initial vowels of polysyllabic words was computed as previously (see $\S 3.2$ ). Results are given in Table 5. An ANOVA was also performed with the $\Delta F_{0}$ value serving as the dependent measure and the Country of the investigation point as the fixed factor (5 levels: Burkina Faso, Ivory Coast, Mali, Senegal and France). The Country effect turned out to be significant $[F(4,8943)=57.782 ; p<.001]$. Pairwise $t$-tests revealed that all the differences are significant with $p<.001$, except the ones between Burkina Faso and Ivory Coast $[p=.025]$ and between Mali and France [ $p=.56]$.

Table 5. Average $\Delta \mathrm{F}_{0}$ (in semitones) between the final and initial vowels of polysyllabic words belonging to the read text.

\begin{tabular}{|c|c|c|c|c|}
\hline $\begin{array}{c}\text { Burkina } \\
\text { Faso }\end{array}$ & Ivory Coast & Mali & Senegal & France \\
\hline 1.5 & 1.1 & 0.5 & -0.4 & 0.6 \\
\hline
\end{tabular}

As in Table 2 for more controlled but more restricted data, the only negative $\Delta F_{0}$ value is observed in Senegal, where it is $-0.4 \mathrm{ST}$ on average. In comparison, the average $\Delta F_{0}$ is $0.6 \mathrm{ST}$ in France. There is thus a 1-semitone difference on average.

A majority of falling pitch movements is noticeable in Senegal ( $59 \%$ vs. $27-44 \%$ in the other investigation points). To investigate whether it is relevant to interpret this finding in terms of word-initial stress, we looked into clitic-polysyllabic word contexts. Pitch contours in semitones with respect to the clitic vowel $F_{0}$ are schematised in Figure 2.

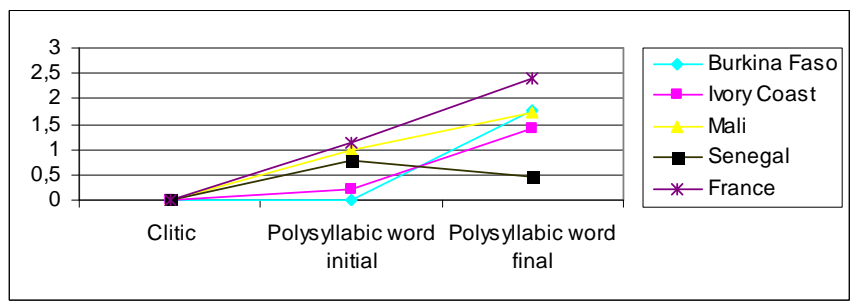

Figure 2: Pitch contours (in ST with respect to the clitic vowel $\mathrm{F}_{0}$ ) of clitic-polysyllabic word sequences

The only rise-fall contour is found in Senegal. It is typical of word-initial stress and may result from a prosodic transfer from Wolof - all but one of the Senegalese speakers were native speakers of Wolof. As Wolof speakers, Northern Mali Songhay and Tamasheq speakers have non-tone languages [10]. There were 5 such speakers in our corpus, whose readings were looked at in more detail. Yet, their prosodic contours are very close to those of the other Malian speakers. These speakers, as native French speakers, may be regarded as having an unspecified tone on the initial vowel of polysyllabic words. By contrast, in Burkina Faso and Ivory Coast, the null or very small pitch difference between the polysyllabic wordinitial vowel and the preceding clitic vowel may be interpreted as a low-high (LH) pattern on the polysyllabic word.

\section{3. $/ R /$ pronunciation analysis}

There were over $1000 / \mathrm{R} /$ occurrences in the PFC text. In order to analyse their pronunciation with the help of automatic alignment with variants, as explained in $\S 4.1$, we resorted to a xenophone to account for the apical [r] realisation. In the automatic alignment results reported in Table 6 , this variant is somewhat disadvantaged as compared to the hand-labelling results of Table 3 . It is reassuringly seldom selected in 
standard French. Nevertheless, it is aligned in the majority of cases (i.e., the apical $[r]$ is found by the aligner to best match the speech signal) in Burkina Faso and Mali, as in the handlabelled stimuli of the perceptual experiment.

Table 6. Percentage of apical, dorsal, elided or labialised $/ R /$ s automatically aligned in the PFC text.

\begin{tabular}{|c|c|c|c|c|c|}
\hline$\% / R /$ & $\begin{array}{c}\text { Burkina } \\
\text { Faso }\end{array}$ & $\begin{array}{c}\text { Ivory } \\
\text { Coast }\end{array}$ & Mali & Senegal & France \\
\hline apical [c] & 62 & 38 & 61 & 39 & 12 \\
dorsal [b] & 26 & 42 & 29 & 50 & 76 \\
elided or & 12 & 20 & 10 & 11 & 11 \\
labialsed [w] & & & & & \\
\hline
\end{tabular}

Among the African French varieties, the dorsal [б] is most often aligned in Senegal, whereas the highest rate of elision/labialisation is achieved in Ivory Coast, in accordance with Table 3. These results suggest that automatic alignment with pronunciation variants is well suited to characterise various realisations of the French /R/.

\section{Conclusions}

In this paper, we tried to assess whether West-African accents from Burkina Faso, Ivory Coast, Mali and Senegal could be distinguished and, if so, on which basis. First, a perceptual experiment was conducted, which showed that West-African accents (especially those of Senegal and Ivory Coast) can be identified by West-African listeners, without the speaking style (text reading or spontaneous speech) and speakers' education level playing a significant role. Then, the most salient cues reported by the listeners were investigated in the experimental corpus. Suprasegmental features $\left(F_{0}\right.$ differences on polysyllabic words) and segmental features (different $/ \mathrm{R} /$ realisations) corroborated listeners' impressions, whereas a subsegmental feature (namely VOT measurements) did not seem to be discriminative.

The next step consisted of checking whether the findings related to the former two relevant features could be generalised to a larger corpus. Making use of automatic alignment, text readings by 52 speakers from Burkina Faso, Ivory Coast, Mali and Senegal were analysed - and compared to the productions of 21 speakers from France. These cues were found to be quite robust for discriminating between the Senegalese and Ivorian accents (the ones identified best in the perceptual experiment): falling (HL) pitch patterns on polysyllabic words and more dorsal $/ \mathrm{R} / \mathrm{s}$ in Senegal, LH pitch patterns on polysyllabic words and more /R/ elision/ labialisation in Ivory Coast.

Why Senegal and Ivory Coast French accents are most distinct may be explained by the status of the French language in these two countries. French is on the way to appropriation and nativisation in Ivory Coast, in the absence of a dominant African language [4]. On the opposite, French is felt as a foreign language in Senegal, where Wolof plays a major role [6]. The Wolof language is characterised by a word-initial stress which may be transferred to French.

Further work is required to find discriminant cues for Mali and Burkina Faso. A more in-depth study is also necessary on spontaneous speech and other investigation points. The same methodology can be applied to other language varieties, including African English or Portuguese varieties such as the ones described by [13].

\section{Acknowledgements}

This work was partially carried out within the framework of the PADE project. Our thanks also go to B. A Boutin for her contribution to this study.

\section{References}

[1] http://www.praat.org

[2] http:// www.speech.kth.se/snack/

[3] Boula de Mareüil, P. \& Boutin, B. A., "Évaluation et identification perceptives d'accents ouest-africains en français", Journal of French Language Studies, 22(2):, in press.

[4] Boutin, B. A. \& Turcsan, G., "La prononciation du français en Afrique : la Côte d'Ivoire", in J. Durand, B. Laks \& C. Lyche [Eds], Phonologie, variation et accents du français, Paris: Hermès, 131-152, 2009.

[5] Boutin B. A. \& Prignitz, G., "Conversation à Ouagadougou (Burkina Faso): parenté à plaisanterie entre Gurma et Yatenga", in S. Detey, J. Durand, B. Laks \& C. Lyche, [Eds], Le français parlé contemporain dans ses variétés. Ressources pour l'étude du français, Paris: Ophrys, 259-272, 2010.

[6] Boutin B. A. \& Gueye, G. M., "French in Senegal after three centuries: A phonological study", in R. Gess, C. Lyche \& T. Meisenburg [Eds], Phonological variation in French: Illustrations from three continents, Amsterdam/ Philadelphia: John Benjamins, to appear.

[7] Cissé, M. T., "Problèmes de phonétique et de phonologie en wolof", SudLangues, 6: 23-62, 2006.

[8] Durand, J., Laks, B. \& Lyche, C., "Un corpus numérisé pour la phonologie du français", in G. Williams [Ed.], $L a$ linguistique de corpus, Rennes: Presses Universitaires de Rennes, 205-217, 2005.

[9] Gauvain, J.-L., Adda, G., Adda-Decker, M., Allauzen, A., Gendner, O., Lamel, L. \& Schwenk, H., "Where are we in transcribing French broadcast news?", Proc. Interspeech, Lisbon, 1665-1668, 2005.

[10] Lyche, C. \& Skattum, I., "Le rôle de la L1 dans le français du Mali : une étude perceptive", Proc. CMLF, New Orleans, 1913-1926, 2010.

[11] Moreau, M.-L., "Le français d'Afrique: Phénomènes d'interférence ou de socialisation? Considérations méthodologiques", in M.-A. Hintze, T. Pooley \& A. Judge [Eds], French accents: phonological and sociolinguistic perspectives, London: AFLS/CiLT, 288-304, 2000.

[12] Moreau, M.-L. \& Thiam, N., “"Comment je reconnais les variétés du wolof' Le discours des adolescents sur les variétés régionales et ethniques du wolof", Sciences et Techniques du Langage, 1: 49-53, 1995.

[13] Rouas, J.-L., Trancoso, I., Viana, C. \& Abreu, M., "Language and variety verification on broadcast news for Portuguese", Speech Communication, 50(11/12): 965979, 2008.

[14] Saerens, M., Serniclaes, W. \& Beeckmans, R., "Acoustic versus contextual factors in stop voicing perception in spontaneous French", Language and Speech, 32(4): 291314, 1989.

[15] Vieru, B., Boula de Mareüil, P. \& Adda-Decker, M., "Characterisation and identification of non-native French accents", Speech Communication, 53: 292-310, 2011. 